Gambaran Ureum dan Kreatinin pada Pasien Penyakit Ginjal Kronik yang Menjalani Hemodialisis

\title{
Overview of Ureum and Creatinine Levels in Hemodialysis Patients with Chronic Kidney Disease
}

\author{
RONI AFRIANSYA* \\ EKO NANING SOFYANITA* \\ SUWARSI**
}

\author{
Jurusan Analis Kesehatan Poltekkes Kemenkes Semarang* \\ Jl. Woltermongisidi No. 115 Pedurungan Tengah; Semarang 50192; Indonesia \\ Rumah Sakit Uumum Daerah Ir. Sukarno Sukoharjo** \\ Jl. Dokter Muwardi No.71, Kabupaten Sukoharjo; Jawa Tengah 57514; Indonesia \\ Email: roniafriansya@gmail.com
}

\begin{abstract}
Abstrak
Penyakit Ginjal Kronik terlihat nyata jika kadar ureum darah lebih dari 200 mg/dl. Uremia menyebabkan gangguan fungsi hampir semua sistem organ seperti; gangguan cairan dan elektrolit, metabolikendokrin, neuromuskular, kardiovaskular dan paru, kulit, gastrointestinal, hematologi serta imunologi. Hemodialisis merupakan suatu usaha untuk mengurangi gejala uremia tersebut, sehingga keadaan klinis pasien juga dapat membaik. Tujuan penelitian ini adalah untuk mengetahui gambaran Ureum dan Kreatinin pada Pasien penyakit ginjal kronik yang melakukan Hemodialisis. Jenis penelitian ini adalah deskriptif observasional. Sampel mencakup semua pasien penyakit ginjal kronik yang menjalani hemodialisis yang memenuhi kriteria inklusi, sehingga didapatkan sebanyak 83 sampel. Jenis data adalah data sekunder yang diperoleh dari rekam medik. Hasil penelitian menunjukkan kebanyakan pasien adalah kelompok usia 40-60 tahun sebanyak 72\% dan sebagian besar jenis kelamin pria sebanyak 51 pasien $(61 \%)$. Gambaran ureum dan kreatinin pada pasien yang menjalani hemodialsis mengalami peningkatan yang sangat tinggi. Pada 83 pasien penyakit ginjal kronik mengalami peningkatan kadar kreatinin serum $(>100 \%)$ dengan rerata kadar kreatinin pada laki-laki sebesar $11,80 \mathrm{mg} / \mathrm{dL}$ dan perempuan sebesar $9,73 \mathrm{mg} / \mathrm{dL}$ serta peningkatan kadar ureum dengan rerata pada laki-laki sebesar $167,09 \mathrm{mg} / \mathrm{dL}$ dan perempuan sebesar 164,39 mg/dL. Simpulan penelitian ini adalah semua pasien dengan penyakit ginjal kronik mengalami peningkatan kadar ureum dan kreatinin lebih dari $100 \%$.
\end{abstract}

Kata Kunci: Penyakit Ginjal Kronik ; Hemodialisis ; Kadar Ureum dan Kreatinin

\section{Abstract}

Chronic Kidney Disease is evident if the blood urea level is more than $200 \mathrm{mg} / \mathrm{dl}$. Uremia causes a malfunction in almost all organ systems such as; fluid and electrolyte disorders, metabolic endocrine, neuromuscular, cardiovascular and pulmonary, skin, gastrointestinal, hematological, and immunological. Hemodialysis is an attempt to reduce the symptoms of uremia so that the patient's clinical condition can also improve. The purpose of this study was to determine the description of Ureum and Creatinine in CKD Patients undergoing Hemodialysis. This type of research is observational descriptive. The sample included all CKD patients undergoing hemodialysis in 2019 who met the inclusion criteria, so as many as 83 samples were obtained. The type of data is secondary data obtained from medical records. The results showed that most patients were in the 40-60 years age group of 72\% and the majority of the male sex were 51 patients (61\%). Urea and creatinine appearance in patients undergoing hemodialysis has increased very high. In 83 patients with CKD increased serum creatinine levels (> 100\%) with a mean creatinine level in men of $11.80 \mathrm{mg} / \mathrm{dL}$ and women 
of $9.73 \mathrm{mg} / \mathrm{dL}$ and an increase in ureum levels with a mean of $167 \mathrm{men}, 09 \mathrm{mg} / \mathrm{dL}$ and women of $164.39 \mathrm{mg} / \mathrm{dL}$. This study concludes that all patients with CKD have increased levels of urea and creatinine by more than $100 \%$.

Keyword: Chronic Kidney Disease ; Hemodialysis ; Ureum and Creatinine Levels

\section{Pendahuluan}

Penyakit ginjal kronik merupakan suatu keadaan gangguan pada ginjal yang ditandai dengan abnormalitas struktur ataupun penurunan fungsi ginjal yang ditunjukkan oleh laju filtrasi glomerulus (GFR) kurang dari $60 \mathrm{~mL} /$ menit per 1,73 $\mathrm{m} 2$ yang berlangsung lebih dari 3 bulan (NKF, 2013; Infodatain, 2017). Selain mengalami penurunan laju filtrasi glomerulus penyakit ginjal kronik ini juga biasanya disertai dengan albuminuria, abnormalitas sedimen urin, elektrolit, histologi dan struktur ginjal. Penyakit ini bersifat ireversibel atau tidak bisa menjadi normal kembali, sehingga intervensi yang dilakukan pada penderita hanyalah mempertahankan fungsi ginjal yang ada dan melakukan hemodialisa untuk menggantikan fungsi ginjal melakukan eliminasi metabolisme tubuh.

Insiden penyakit ginjal kronik terus mengalami peningkatan setiap tahunnya dan menjadi masalah kesehatan utama pada seluruh dunia, akibat dari penyakit ginjal kronik ini, resiko kejadian penyakit jantung dan pembuluh darah serta meningkatkan angka kesakitan dan kematian (Setyaningsih, 2013). Ada sekitar 1 dari 10 populasi dunia teridentifikasi mengalami penyakit ginjal kronik. Hasil studi systematic review dan meta analisys yang dilakukan oleh Hill et al (2016) menunjukkan 13,4\% penduduk dunia menderita penyakit ginjal kronik.

Prevalensi penyakit ginjal kronik di Indonesia pada pasien usia lima belas tahun keatas yang didata berdasarkan jumlah kasus yang didiagnosis dokter Mengalami peningkatan dari 2,0 tahun 2013 menjadi 3,8 di tahun 2018. Prevalensi gagal ginjal kronik meningkat seiring bertambahnya usia, dimana usia $15-24$ tahun $(1,33 \%)$ dan terus mengalami peningkatan hingga $8,23 \%$ pada usia $65-74$. Prevalensi pada laki-laki (4,17\%) lebih tinggi dari perempuan (3,52\%) (Kemenkes RI, 2018).

Prevalensi penyakit ginjal kronik di Jawa Tengah juga mengalami peningkatan dari tahun 2013 ke tahun 2018. Prevalensi Gagal Ginjal Kronis berdasarkan Diagnosis Dokter pada Penduduk Umur $\geq 15$ tertinggi pada usia $65-74$ yaitu $0,84 \%$ dan laki-laki $(0,45 \%)$ sedangkan perempuan $(0,39 \%)$. Namun hal ini berbeda dengan kejadian di Sumatera barat dimana kerjadian tertingga pada kelompok umur 45-54 tahun sebanyak 0,6\%. Perbandingan penyakit ginjal kronik berdasarkan jenis kelamin pria dan wanita adalah tiga berbanding dua (Kemenkes RI 2018; Riskesdas Sumatera barat, 2013).

Mekanisme dasar terjadinya penyakit ginjal kronik adalah adanya cedera jaringan yang kemudian menyebabkan pengurangan massa ginjal, dan mengakibatkan terjadinya proses adaptasi berupa hipertrofi pada jaringan ginjal normal yang masih tersisa dan hiperfiltrasi. Proses adaptasi tersebut berlangsung hanya sementara, kemudian berubah menjadi suatu proses maladaptasi berupa sklerosis nefron yang masih tersisa. Penyakit ginjal kronik Pada stadium dini, menyebabkan terjadi kehilangan daya cadang ginjal, pada keadaan dimana basal laju filtrasi glomerulus (LFG) masih normal atau malah meningkat. Secara perlahan tapi pasti akan terjadi penurunan fungsi nefron yang progresif (Suwitra K, 2014).

Pasien penyakit ginjal kronik dengan ureum darah kurang dari $150 \mathrm{mg} / \mathrm{dl}$, biasanya tanpa keluhan maupun gejala. Gambaran klinis akan terlihat nyata bila ureum darah lebih dari $200 \mathrm{mg} / \mathrm{dl}$ karena konsentrasi ureum darah merupakan indikator adanya retensi sisa-sisa metabolisme protein di dalam tubuh (Sukandar E, 2006). Uremia menyebabkan gangguan fungsi hampir semua sistem organ, seperti gangguan cairan dan elektrolit, metabolikendokrin, neuromuskular, kardiovaskular dan paru, kulit, gastrointestinal, hematologi serta imunologi (Skorecki, K., \& Bargman, J. M, 2012).

Menurut KDIGO, penyakit ginjal kronik dengan tanda-tanda kegagalan ginjal (serositis, gangguan keseimbangan asam-basa atau elektrolit, pruritus), kegagalan pengontrolan volume 
dan tekanan darah, gangguan status gizi yang refrakter, dan gangguan kognitif membutuhkan terapi hemodialisis. Pada penderita yang sudah mencapai penyakit ginjal kronik derajat IV (eGFR $<30 \mathrm{~mL} / \mathrm{menit} / 1,73 \mathrm{~m} 2$ ) juga harus dimulai terapi hemodialisis (Kemenkes RI 2018).

Data mengenai gambaran Ureum dan Kreatinin pada penderita penyakit ginjal kronik yang sudah melakukan hemodialisis belum banyak tersedia, dan data yang tersedia kebanyakan data tentang kualitas hidup pasien penyakit ginjal kronik yang melakukan hemodialisis. Hal ini membuat peneliti tertarik untuk melakukan penelitian mengenai gambaran Ureum dan Kreatinin pada Pasien penyakit ginjal kronik yang melakukan Hemodialisis.

\section{Metode}

Penelitian ini merupakan studi deskriptif observasional yang telah dilakukan di bagian rekam medik dan unit hemodialisis di salah satu Rumah Sakit. Sampel penelitian ini mencakup semua penderita penyakit ginjal kronik dewasa yang menjalani Hemodialisis (HD) dengan data rekam medis lengkap berupa umur dan jenis kelamin, data gambaran klinis dan hasil laboratorium. Pengambilan sampel dilakukan dengan mengambil seluruh sampel yang sesuai kriteria inklusi, yaitu sebanyak 83 sampel.

\section{Hasil dan Pembahasan}

Penelitian yang telah dilakukan di bagian rekam medik dan unit hemodialisis di salah satu Rumah Sakit mendapatkan jumlah pasien penyakit ginjal kronik yang menjalani hemodialisis pada tahun 2019 sebanyak 170 orang dengan rekam medik yang memenuhi kriteria sampel sebanyak 83 rekam medik.

Tabel 1. Karakteristik dasar penderita penyakit ginjal kronik yang menjalani hemodialisis berdasarkan usia.

\begin{tabular}{ccc}
\hline Karakteristik & f & \% \\
\hline Usia: & & \\
$<40$ & 8 & $10 \%$ \\
$40-60$ & 60 & $72 \%$ \\
$>60$ & 15 & $18 \%$ \\
\hline
\end{tabular}

Berdasarkan data pada tabel 1, penderita penyakit ginjal kronik yang menjalani hemodialisis terbanyak pada kelompok umur 40 - 60 tahun (72\%). Hal ini sejalan dengan penelitian yang dilakukan oleh Wahyuni dkk (2018) tentang hubungan lama menjalani terapi HD dengan kualitas hidup pasien penyakit ginjal kronik dengan DM di salah satu Rumah sakit lain dimana pasien yang terbanyak pada usia 45 - 60 tahun yaitu 74,1\%. Hasil ini sesuai dengan penelitian Alfonso et al (2016) yang menunjukan hasil yang terbanyak yaitu pada usia 66-75 tahun $(37,14 \%)$, dan sesuai juga dengan data dari United States Renal Data System Annual Data Report (2013) yang menunjukkan bahwa usia 45-64 tahun (45\%) merupakan kelompok usia terbanyak yang menderita penyakit ginjal kronik (Nicola L, et al, 2012). Sedangkan data dari National Health Service (NHS) di Inggris menunjukkan bahwa prevalensi pasien penyakit ginjal kronik stadium 5 pada kelompok usia 18-25 tahun adalah kurang dari $1 \%$ dan meningkat pada kelompok usia 85 tahun (44,75\%). Dapat kita ketahui bahwa prevalensi penyakit ginjal kronik meningkat seiring dengan bertambahnya usia.

Tabel 2. Karakteristik dasar penderita penyakit ginjal kronik yang menjalani hemodialisis berdasarkan jenis kelamin

\begin{tabular}{ccc}
\hline Karakteristik & f & \% \\
\hline Jenis Kelamin: & & \\
Laki-laki & 51 & $61 \%$ \\
Perempuan & 32 & $39 \%$ \\
\hline
\end{tabular}


Berdasarkan data pada Tabel 2, terdapat 51 orang laki-laki (61\%) dan 32 orang perempuan (39\%). Hasil penelitian ini sama dengan hasil penelitian yang dilakkan Alfonso et al (2016) yang menunjukan hasil 21 orang laki-laki (60\%) dan 14 orang perempuan (40\%). Dan hasil ini sesuai juga dengan data dari United States Renal Data System Annual Data Report (2013) yang menunjukkan bahwa pasien laki-laki $(56,8 \%)$ lebih banyak dari perempuan $(43,2 \%)$. Hasil tersebut juga sama seperti penelitian yang dilakukan oleh Pura dkk (2009) di salah satu Rumah Sakit lain menunjukkan perbandingan antara jumlah laki-laki dan perempuan adalah 2:1. Namun hasil ini berbeda dengan data dari National Health Service di Inggris yang menunjukkan bahwa pasien perempuan $(10,6 \%)$ lebih banyak dari laki-laki (5,8\%). Penelitian yang dilakukan oleh Tjekyan (2014) di salah satu Rumah Sakit lain juga menunjukkan bahwa pasien perempuan $(56,3 \%)$ lebih banyak dari laki-laki $(43,7 \%)$. Perbandingan tersebut menunjukkan bahwa jenis kelamin tidak berpengaruh pada prevalensi penyakit ginjal kronik.

Tabel 3. Distribusi Hasil pemeriksaan Kreatinin penderita penyakit ginjal kronik yang menjalani hemodialisis

\begin{tabular}{cccc}
\hline Jenis Kelamin & Jumlah & $\%$ & $\begin{array}{c}\text { Rerata kadar kreatinin } \\
(\mathrm{mg} / \mathrm{dL})\end{array}$ \\
\hline Laki-laki & 51 & $61 \%$ & 11,80 \\
\hline Perempuan & 32 & $39 \%$ & 9,73 \\
\hline
\end{tabular}

Pada Tabel 3 dapat dilihat bahwa 83 pasien penyakit ginjal kronik mengalami peningkatan kadar kreatinin serum $(>100 \%)$ dengan rerata kadar kreatinin pada laki-laki sebesar $11,80 \mathrm{mg} / \mathrm{dL}$ dan perempuan sebesar $9,73 \mathrm{mg} / \mathrm{dL}$. Hasil tersebut menunjukkan bahwa laki-laki memiliki kadar kreatinin yang lebih tinggi daripada perempuan. Rata-rata kadar kreatinin semua pasien pada penelitian ini adalah sebesar $11 \mathrm{mg} / \mathrm{dL}$, dengan kadar kreatinin terendah $1,77 \mathrm{mg} / \mathrm{dL}$ dan kadar kreatinin tertinggi 34,46 mg/dL. Hasil ini tidak jauh berbeda dengan penelitian yang dilakukan di salah satu Rumah Sakit yang menunjukkan bahwa terdapat 31 pasien $(93,9 \%)$ penyakit ginjal kronik yang memiliki kadar kreatinin tinggi (Martini, 2010). Kreatinin disintesis di otot skelet sehingga kadarnya bergantung pada massa otot. Laki-laki memiliki massa otot yang lebih tinggi daripada perempuan sehingga kadar kreatinin pada laki-laki lebih tinggi daripada perempuan (Banerjee, 2005).

Hasil pemeriksaan laboratorium (Tabel 3) tersebut juga sesuai dengan teori yang mengatakan bahwa jika terjadi disfungsi renal maka kemampuan filtrasi kreatinin akan berkurang dan kreatinin serum akan meningkat. Peningkatan kadar kreatinin serum dua kali lipat mengindikasikan adanya penurunan fungsi ginjal sebesar $50 \%$, demikian juga peningkatan kadar kreatinin serum tiga kali lipat merefleksikan penurunan fungsi ginjal sebesar 75\%. Fungsi ginjal yang terpenting salah satunya adalah ekskresi produk sisa metabolik seperti kreatinin (Guyton dan Hall, 1977). Oleh sebab itu kadar kreatinin serum digunakan sebagai indikator penting untuk mengetahui fungsi ginjal.

Tabel 4. Distribusi Hasil pemeriksaan Ureum penderita penyakit ginjal kronik yang menjalani hemodialisis

\begin{tabular}{cccc}
\hline Jenis Kelamin & Ju mlah & $\%$ & $\begin{array}{c}\text { Rerata kadar ureum } \\
(\mathrm{mg} / \mathrm{dL})\end{array}$ \\
\hline Laki-laki & 51 & $61 \%$ & 167,09 \\
\hline Perempuan & 32 & $39 \%$ & 164,39 \\
\hline
\end{tabular}

Pada Tabel 4, dapat dilihat dari 83 pasien penyakit ginjal kronik seluruhnya $(>100 \%)$ mengalami peningkatan kadar ureum dengan rerata kadar ureum pada laki-laki sebesar $167,09 \mathrm{mg} / \mathrm{dL}$ dan perempuan sebesar 164,39 mg/dL. Dari hasil tersebut dapat dilihat bahwa laki-laki memiliki kadar ureum lebih tinggi daripada perempuan. Peningkatan kadar ureum 
pada 83 pasien penyakit ginjal kronik menunjukkan bahwa meningkatnya ureum dalam darah dapat menjadi sebuah tanda kerusakan ginjal.

Peningkatan kadar ureum darah bergantung pada penurunan fungsi filtrasi glomerulus. Penurunan fungsi ginjal 15\% $(<15 \mathrm{ml} / \mathrm{mnt})$ mengindikasikan adanya gagal ginjal dan uremia. Fungsi ginjal yang penting yaitu mengatur keseimbangan asam basa, hormonal/eritropoetin dan ekskresi sampah sisa metabolisme seperti ureum. Apabila ureum tidak di keluarkan dari dalam tubuh maka dapat menyebabkan sindrom uremia (Wilson, 2005). Sindrom uremia ini terutama terjadi pada penderita penyakit ginjal yang kronis dan akan memberikan manifestasi pada bagian anggota tubuh yang lain seperti gastrointenstinal, hematologi, kulit, kardiovaskuler, saraf dan otot, endokrin dan sistem lainnya berupa kerusakan. Hal inilah yang mendasari pengetahuan jika terjadi peningkatan kadar ureum maupun kreatinin dapat di gunakan sebagai indikator penting untuk mengetahui fungsi ginjal.

\section{Simpulan dan Saran}

\section{Simpulan}

Berdasarkan hasil penelitian ini maka dapat disimpulkan bahwa pada penyakit ginjal terjadi peningkatan kadar kreatinin dan ureum serum. Peningkatan kadar kreatinin dan ureum serum lebih banyak pada laki-laki dibandingkan perempuan dan peningkatan kadar tersebut terjadi pada semua usia.

\section{Saran}

Perlu dilakukan penelitian yang serupa dengan melihat aspek lama menjalani Hemodialisis serta kualitas hidup pasien penyakit ginjal kronik yang menjalani hemodialisis.

\section{Daftar Pustaka}

Alfonso, A. A., Mongan, A. E., dan Memah, M. F. (2016). Gambaran kadar kreatinin serum pada pasien penyakit ginjal kronik stadium 5 non dialisis. eBiomedik, 4(1).

Banerjee A. (2005). Renal physiology. In : Clinical physiology an examination primer. USA : Cambridge University Press;.p.61.

Guyton AC, Hall JE. Pembentukan urin oleh ginjal: 1. Filtrasi glomerulus, aliran darah ginjal, dan pengaturannya. Dalam: Buku ajar fisiologi kedokteran. Edisi 9. Jakarta: EGC; 1997.p.397-8.

Martini, M. (2010). Hubungan Tingkat Asupan Protein Dengan Kadar Ureum Dan Kreatinin Darah Pada Penderita Gagal Ginjal Kronik Di Rsud Dr. Moewardi Surakarta (Doctoral dissertation, Universitas Muhammadiyah Surakarta).

National Kidney Foundation - Kidney Disease Improving Global Outcomes (NKF-KDIGO). KDIGO. (2012). clinical practice guideline for the evaluation and management of chronic kidney disease. ISN. 2013;3(1):1-163.

National Institute for Helath Research. (2014). Point-of-care creatinine testing for the detection and monitoing of chronic kidney disease. Oxford Journal.1-3.

Hill, N. R., Fatoba, S. T., Oke, J. L., Hirst, J. A., O’Callaghan, C. A., Lasserson, D. S., and Hobbs, F. R. (2016). Global prevalence of chronic kidney disease-a systematic review and meta-analysis. PloS one, 11(7).

Pura, L., Supriyadi, R., Nugraha, G. I., Bandiara, R., dan Soelaeman, R. (2009). Hubungan laju filtrasi glomerulus dengan status nutrisi pada penderita penyakit ginjal kronik predialisis. Majalah Kedokteran Bandung, 41(1).

Suwitra, K. (2014). Penyakit Gagal Ginjal Kronik. Buku Ajar Ilmu Penyakit Dalam. Edisi ke-5. Jakarta: Internal publishing.

Sukandar, E. (2006). Nefrologi klinik. Edisi ketiga. Bandung: Pusat Informasi Ilmiah (PII) Bagian Ilmu Penyakit Dalam Fakultas Kedokteran UNPAD.

Skorecki, K., and Bargman, J. M. (2012). Chronic Kidney Disease. Harrison's Principals of Internal Medicine. Newyork: McGraw-Hill Inc, 18(2), 2308. 
Tjekyan R. (2014). Prevalensi dan Faktor Risiko penyakit ginjal kronik di RSUP Dr. Mohammad Hoesin Palembang Tahun 2012. Jurnal Fakultas Kedokteran Universitas Sriwijaya. 277.

Wahyuni, P., Miro, S., dan Kurniawan, E. (2018). Hubungan Lama Menjalani Hemodialisis dengan Kualitas Hidup Pasien Penyakit Ginjal Kronik dengan Diabetes Melitus di RSUP Dr. M Djamil Padang. Jurnal Kesehatan Andalas, 7(4), 480-485.

Wilson, LM. (2005). Penyakit ginjal kronik stadium akhir: sindrom uremik. In: Pendit BU, Hartanto H, Wulansari P, Mahanani DA, Susi N (editor Bahasa Indonesia). Patofisiologi konsep klinis proses-proses penyakit Vol-2 (6th ed). Jakarta: EGC, 45.p. 951-62.

De Nicola, L., et al. (2012). The effect of increasing age on the prognosis of non-dialysis patients with chronic kidney disease receiving stable nephrology care. Kidney international, 82(4), 482-488. 